\title{
Pengaruh Pemberian Jus Tomat (Solanum lycopersicum L.) terhadap Kadar Kolesterol LDL Tikus Putih (Rattus norvegicus) Jantan Galur Wistar yang Diinduksi Aloksan
}

\author{
Leny Alimatul Husna*, Louis Djoko, Fitri Handajani, Tri Martini \\ Fakultas Kedokteran Universitas Hang Tuah \\ *e-mail: lenyhsn@gmail.com
}

\begin{abstract}
Abstrak
Hiperkolesterolemia merupakan faktor resiko terjadinya gangguan kardiovaskuler pada diabetes mellitus. Pada diabetes mellitus kekurangan insulin meningkatkan lipolisis sehingga asam lemak bebas meningkat sehingga meningkatan kadar kolesterol total dan kolesterol LDL. Tomat mengandung likopen yang dapat menurunkan kadar kolesterol LDL karena mampu menghambat HMG-KoA reduktase. Penelitian ini untuk mengetahui pengaruh pemberian jus tomat (Solanum lycopersicum L.) terhadap kadar kolesterol total dan LDL tikus putih (Rattus norvegicus) jantan galur wistar yang diinduksi aloksan. 24 ekor yang dibagi menjadi 3 kelompok: 1). Kelompok kontrol negatif tanpa perlakuan 2). Kelompok kontrol positif hewan coba yang diinduksi aloksan 3). Kelompok perlakuan yang diinduksi aloksan dan diberi jus tomat dengan dosis $11 \mathrm{gram} / \mathrm{KgBB}$ selama 14 hari. Uji One-Way Annova menunjukkan peningkatan kadar kolesterol LDL yang signifikan antara kelompok kontrol positif dan kelompok hewan kontrol negatifnamun tidak pada kadar total kolesterol. Rerata kadar total kolesterol dan LDL pada kelompok perlakuan menunjukkan penurunan yang tidak signifikan di bandingkan kelompok hewan coba yang diinduksi aloksan. Pemberian aloksan dengan dosis $150 \mathrm{mg} / \mathrm{Kg}$ BB dapat meningkatkan kadar kolesterol LDL secarabermakna namun tidak pada kadar total kolesterol. Pemberian jus tomat dengan dosis 11 gram $/ \mathrm{KgBB}$ cenderung menurunkan rerata kadar total kolesterol dan LDL.
\end{abstract}

Kata Kunci: Solanum lycopersicum L., Aloksan, kolesterol LDL

\section{The Effect of Tomato Juice (Solanum lycopersicum L.) to LDL Cholesterol Level of Male Wistar Rats (Rattus norvegicus) Induced by Alloxan}

\begin{abstract}
Hypercholesterolemia is a risk factor for cardiovascular disorders in diabetes mellitus. Diabetes mellitus have low insulin level will increasing lipolysis and free fatty acids then followed by an increase in cholesterol total and LDL. Lycopene in tomatoes can reduce $L D L$ and cholesterol total because it can inhibit HMG-CoA reductase. This study aimed to show the effect of tomato juice (Solanum lycopersicum L.) to LDL and cholesterol total level of male Wistar rats (Rattus norvegicus) induced by alloxan. This research were used 24 male wistar rats divided into 3 groups: 1). Negative control group of rats without treatment 2). Positive control Group of rats induced alloxan 3). Treatment Group of rats induced alloxan and given 11 $\mathrm{gr} / \mathrm{KgBW}$ tomato juice on day 4, for 14 days. The One-Way Annova test showed a significant increase in LDL cholesterol levels between control positive group and control negative group.
\end{abstract}


Pengaruh Pemberian Jus Tomat (Solanum lycopersicum L.) terhadap Kadar Kolesterol LDL...

Leny Alimatul Husna, Louis Djoko, Fitri Handajani, Tri Martini

LDL and total cholesterol levels of treatment showed to decreased LDL and total cholesterol level compared to positive control group $(=8.38 \mathrm{mg} / \mathrm{dl})$ but the difference was not significant $(p=0.858)$. This study showed that administration of alloxan at the dose of $150 \mathrm{mg} / \mathrm{KgBW}$ significantly increased blood LDL cholesterol but not total cholesterol level. Administration of tomato juice at a dose of $11 \mathrm{grams} / \mathrm{KgBW}$ tend to reduce $L D L$ and total cholesterol level of alloxan-induced althought statistically was not significant, because tomato contain lycopene that function as antioxidant.

Keywords: Tomato juice (Solanum lycopersicum L.), Alloxan, LDL cholesterol

\section{PENDAHULUAN}

Kekurangan insulin dalam tubuh mempengaruhi kadar glukosa darah juga berpengaruh terhadap penghambatan lipogenesis dan terjadinya peningkatan lipolisis. Hormon insulin yang mengalami penurunan fungsi menyebabkan aktivitas enzim lipoprotein lipase juga menurun. Akibatnya, pemecahan lipoprotein darah juga menurun. Kolesterol dan trigliserida disirkulasikan darah dalam bentuk lipoprotein sehingga pada penderita Diabetes Melitus (DM), kandungan lipoprotein yang tinggi juga diikuti peningkatan kadar kolesterol dan trigliserida (Setiawan, 2010)

Aloksan (2,4,5,6-tetraoxypyrimidine; 2,4,5,6-pyrimidinetetrone) adalah pirimidin oksigen derivatif sebagai aloksan hidrat dalam larutan encer (Rohilla dan Ali 2012). Reaksi aloksan akan merusak sel beta pankreas (Lenzen, 2008). Aloksan menimbulkan efek hiperglikemi yang permanen dalam waktu dua sampai tiga hari (Setiawan, 2010). Aloksan mempunyai mode toksisitasnya melalui siklus redoks Copyright (c) 2019 Leny Alimatul Husna
(Lenzen, 2008). Aloksan dapat menginduksi diabetes pada tikus jika diberikan secara intravena, intraperitoneal atau subkutan (Hermansyah, 2014). Induksi aloksan mengakibatkan terjadinya penurunan sintesa insulin sehingga hewan coba menjadi Diabetes. Hal ini mengakibatkan peningkatan kadar glukosa darah dan diikuti peningkatan lipolisis sehingga terjadi peningkatan kadar kolesterol total dan kolesterol LDL.

Pada umumnya tomat merupakan makanan yang banyak dipakai oleh orang Indonesia sebagai campuran masakan, sayur, ataupun lalapan. Masyarakat Indonesia sering mengolah tomat dengan berbagai metode, salah satunya adalah digoreng atau dibuat jus. Metode tersebut akan menambah daya tarik. Penelitian terdahulu menunjukkan bahwa pengolahan pada tomat akan lebih meningkatkan kadar likopen dari tomat dan efek antioksidan (Charles, 2014).

Beberapa penelitian menunjukkan bahwa buah tomat dapat memperbaiki profil lipid darah. Tomat memiliki 
komponen bioaktif dan zat gizi seperti potassium, asam folat, vitamin $\mathrm{A}, \mathrm{C}$, dan $\mathrm{E}$. Selain itu, tomat mengandung campuran dari karotenoid antara lain carotenoid lycopene (LYC), $y$-carotene, phytoene (PE), neurosprene, phytofluene (PF), B-carotene, dan lutein (Engelmann et al., 2011). Kandungan likopen dari tomat mampu menurunkan kadar LDL dengan cara mencegah aktivitas dari HMG-COA reductase yang merupakan enzim kunci pada sintesis kolesterol sehingga sintesis kolesterol terhambat (Latifah, 2013).

Berdasarkan uraian di atas maka perlu dilakukan penelitian mengenai pengaruh pemberian jus tomat (Solanum lycopersicum L.) tehadap kadar LDL darah pada tikus putih (Rattus norvegicus) yang telah diinduksi aloksan. Dan diharapkan penelitian ini dapat bermanfaat untuk ilmu kesehatan.

\section{METODE}

Penelitian ini merupakan penelitian eksperimental post test only control group desain. Sampel yang digunakan yaitu tikus jantan strain Wistar berumur 10-12 minggu dengan berat badan 120-160 gram sebanyak 24 ekor dibagi menjadi 3 kelompok masing-masing 8 ekor. Penelitian dilakukan di Laboratorium Biokimia Fakultas Kedokteran Umum Universitas Hang Tuah Surabaya.

Copyright (c) 2019 Leny Alimatul Husna
Hewan coba dibagi dalam 3 kelompok:

Kontrol negatif: Kelompok tikus putih (Rattus norvegicus) tanpa perlakuan.

Kontrol positif (Diabetes): Kelompok tikus putih (Rattus norvegicus) yang diinjeksi aloksan $150 \mathrm{mg} / \mathrm{KgBB}$ yang diberikan secara intraperitoneal

Perlakuan: Kelompok tikus putih (Rattus norvegicus) ke-1 diinjeksi aloksan 150 $\mathrm{mg} / \mathrm{KgBB}$ yang diberikan secara intraperitoneal pada pagi hari ditunggu selama 3 hari. Kemudian pada hari ke-4 hewan coba diberi jus tomat (Solanum lycopersicum L.) $11 \mathrm{gr} / \mathrm{KgBB}$ setiap hari selama 14 hari dengan sonde intragastric pada pagi hari.

Kemudian pada hari ke-18 dilakukan pengambilan darah seluruh tikus putih jantan galur Wistar pada ketiga kelompok untuk dilakukan pemeriksaan kadar total kolesterol dan LDL.

\section{Pembuatan jus tomat.}

Tomat segar dicuci terlebih dahulu dan ditimbang dengan berat 200 gram, kemudian di potong kecil-kecil selanjutnya diblender sampai halus sekitar 5 menit. Setelah halus disaring dengan penyaring sehingga didapatkan cairan dengan volume $100 \mathrm{ml}$. Volume $100 \mathrm{ml}$ ditimbang menghasilkan berat 97,4 gram, jadi 1 gram sama dengan $1,025 \mathrm{ml}$. 
Pengaruh Pemberian Jus Tomat (Solanum lycopersicum L.) terhadap Kadar Kolesterol LDL... Leny Alimatul Husna, Louis Djoko, Fitri Handajani, Tri Martini

\section{Induksi aloksan}

Injeksi aloksan monohidrat dengan dosis $23,22 \mathrm{mg}$ yang dilarutkan ke dalam $\mathrm{NaCL} 0,9$ \% secara intraperitoneal. Larutan aloksan monohidrat diinjeksi hanya 1 kali kemudian ditunggu selama 3 hari untuk mencapai kondisi hiperglikemia.

\section{Pemeriksaan kadar LDL darah}

Penentuan kadar LDL menggunakan alat Cobas integra 400/ 400 Plus LDL-Cholesterol plus $2^{\text {nd }}$ generation dengan metode tes kolotimetrik enzimatik homogen. Metode untuk mengukur kadar kolesterol LDL direct ini memanfaatkan solubilisasi miselary selektif dari kolesterol LDL oleh deterjen non-ionik dan interaksi dari komponen gula dan lipoprotein (VLDL dan kilomikron). Ketika deterjen dimasukkan dalam metode enzimatik untuk mengukur kadar kolesterol (cholesterol esterase cholesterol oxidase coupling reaction), reaktivitas relatif dari kolesterol dalam fraksi lipoprotein meningkat sesuai urutan berikut ini $\mathrm{HDL}<$ kilomikron < VLDL < LDL. Dengan adanya $\mathrm{Mg++}$, komponen gula secara signifikan mereduksi reaksi enzimatik dari pengukuran kolesterol dalam VLDL dan kilomikron. Kombinasi komponen gula dengan deterjen memungkinkan pengukuran selective kolesterol LDL dalam serum. Detergent Cholesterol Esterase Copyright (c) 2019 Leny Alimatul Husna
Kolesterol LDL + H2O Kolesterol + asam lemak bebas (Solubilisasi Micellary selektif) cholesterol oxidase Kolesterol LDL +02 A4-cholestenone $+\mathrm{H} 202$ peroksidase $2 \mathrm{H} 2 \mathrm{O} 2+4$-aminoantipyrine + HSDA + $\mathrm{H}++$ $\mathrm{H}_{2} \mathrm{O}$ Pigmen biru ungu $+5 \mathrm{H}_{2} \mathrm{O}$

\section{Pemeriksaan kadar kolesterol total} Menggunakan alat Chemistry Autoanalyzer Cobas Integra 400. Cobas Integra 400 merupakan reagen diagnostik in vitro untuk mengetahui konsentrasi kolesterol total secara kuantitatif pada serum dan plasma.

Prosedur: Intensitas warna yang terbentuk sesuai dengan konsentrasi kolesterol yang dapat ditentukan dengan mengukur absorbansinya pada rentang panjang gelombang 480-550 $\mathrm{nm}$.

\section{HASIL PENELITIAN}

Berdasarkan hasil penelitian yang di lakukan di Laboratorium IImu Biokimia Fakultas Kedokteran Umum Universitas Hang Tuah Surabaya dengan menggunakan 24 ekor tikus jantan galur Wistar dengan berat badan 150-200 gram, usia 2-3 bulan yang dibagi dalam kelompok kontrol negatif tanpa perlakuan, kelompok kontrol positif dengan induksi aloksan, dan kelompok perlakuan yang diberi jus tomat, dengan tiap kelompok terdiri dari 8 ekor. 
ISSN 1978-2071 (Print); ISSN 2580-5967 (Online) Jurnal IImiah Kedokteran Wijaya Kusuma 8(1) : 14-25, Maret 2019

Data hasil pengukuran rerata kadar glukosa darah didapatkan hasil bahwa pada kelompok kontrol negatif sebesar
$195,88 \mathrm{mg} / \mathrm{dl}$ dan kelompok kontrol positif sebesar 401,50 dapat dilihat pada Gambar 1.

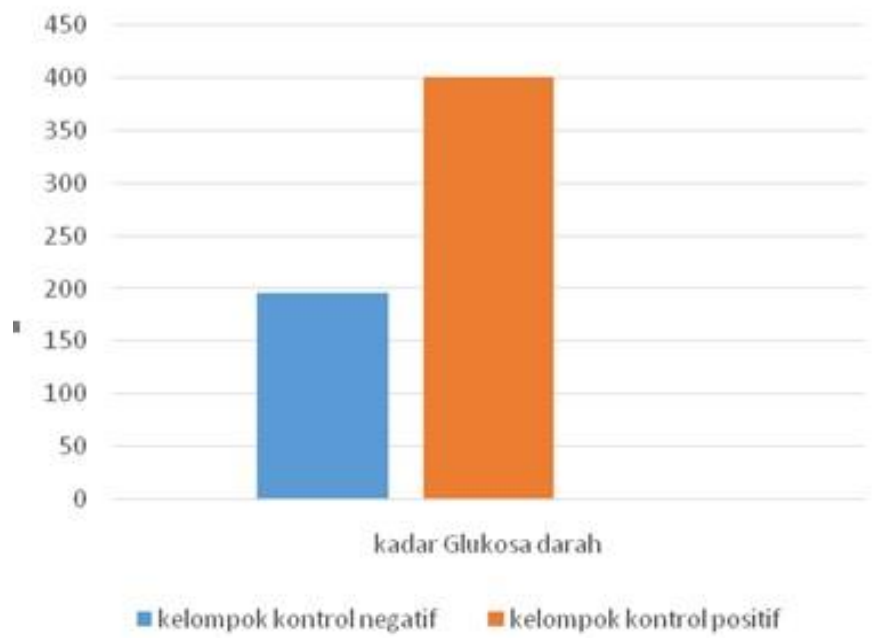

Gambar 1. Kadar glukosa darah kelompok kontrol negatif hewan coba tanpa induksi aloksan dan kelompok kontrol positif hewan coba yang diinduksi aloksan.

Dari gambar di atas dapat disimpulkan bahwa sudah terjadi hiperglikemia pada kelompok kontrol positif hewan coba yang diinduksi aloksan.

Data rerata kadar total kolesterol dan LDL darah kelompok hewan coba tanpa diinduksi aloksan, kelompok hewan coba yang diinduksi aloksan, dan kelompok hewan coba yang diinduksi aloksan dan diberi jus tomat dapat dilihat pada Gambar

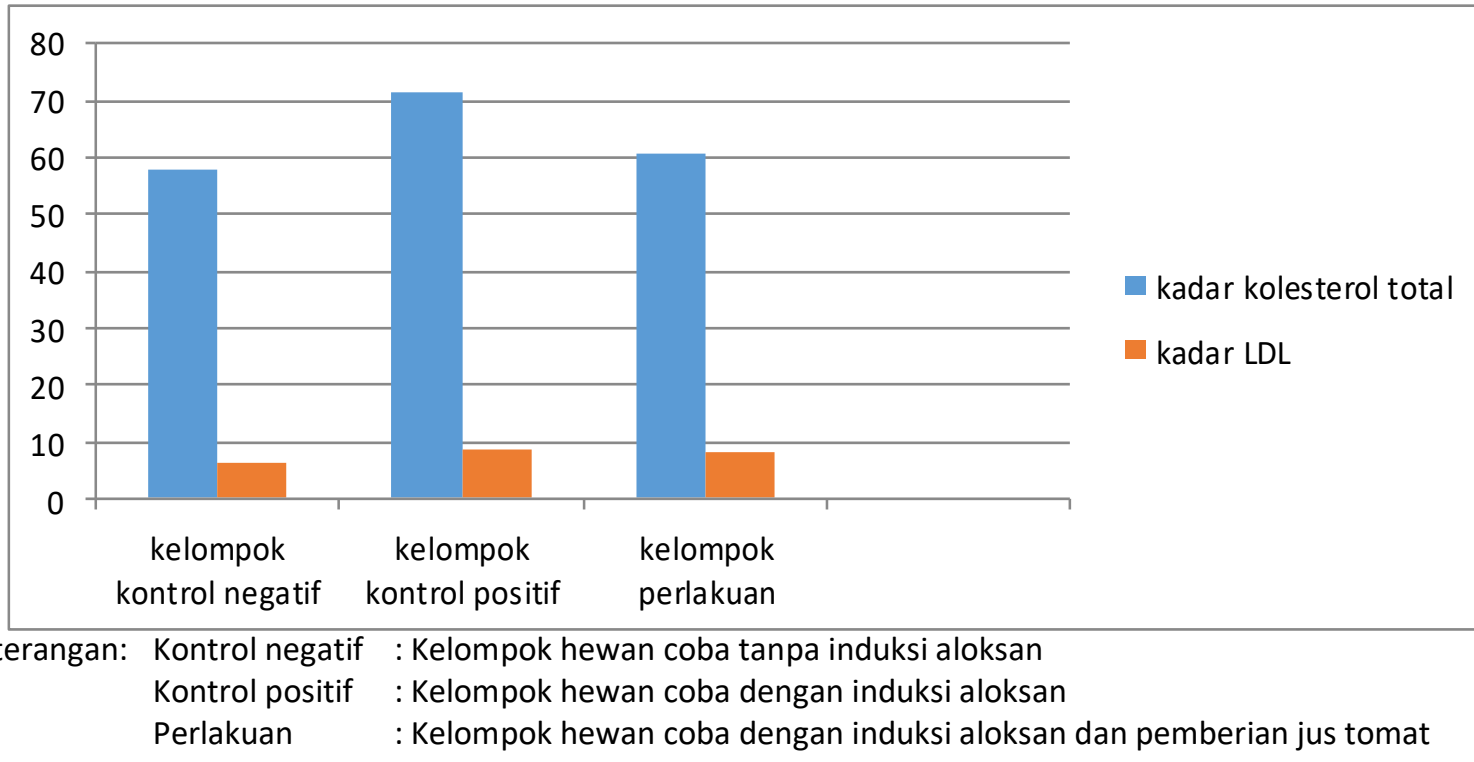

Gambar 2. Rerata kadar total kolesterol dan LDL darah kelompok tanpa induksi aloksan, kelompok yang diinduksi aloksan dan kelompok hewan coba yang diinduksi aloksan dan diberi jus tomat 
Pengaruh Pemberian Jus Tomat (Solanum lycopersicum L.) terhadap Kadar Kolesterol LDL... Leny Alimatul Husna, Louis Djoko, Fitri Handajani, Tri Martini

Dilakukan uji normalitas dan uji homogneitas levene pada kadar kolesterol LDL diperoleh hasil bahwa pada ketiga kelompok diatas memilki distribusi normal dan varian homogen selanjutnya dilakukan uji One Way ANOVA, sedangkan pada kadar kolesterol total data berdistribusi normal tetapi tidak homogen sehingga di lakukan uji kruakal Wallis.
Hasil uji One-Way Anova kolesterol LDL darah kelompok hewan coba tanpa induksi aloksan, kelompok hewan coba yang diinduksi aloksan, dan kelompok hewan coba yang diinduksi aloksan dan diberi jus tomat menunjukkan adanya perbedaan yang bermakna antar kelompok, sehingga di lanjutkan dengan uji post hoc LSD seperti pada Tabel 1.

Tabel 1. Uji LSD kolesterol LDL darah kelompok hewan coba tanpa induksi aloksan, kelompok hewan coba yang diinduksi aloksan dan kelompok hewan coba yang diinduksi aloksan dan diberi jus tomat.

\begin{tabular}{lllllll}
\hline & \multicolumn{3}{c}{$\begin{array}{l}\text { Mean } \\
\text { Difference }\end{array}$} & & & \multicolumn{2}{c}{ 95\% Confidence Interval } \\
\cline { 3 - 6 } (I) Kontrol & (J) Kontrol & $(\mathrm{I}-\mathrm{J})$ & Std. Error & Sig. & Lower Bound & Upper Bound \\
\hline kontrol negatif & Kontrol positif & $-2,25000^{*}$ &, 69222 &, 004 & $-3,6895$ &,- 8105 \\
& Perlakuan & $-2,12500^{*}$ &, 69222 &, 006 & $-3,5645$ &,- 6855 \\
\multirow{3}{*}{ Kontrol positif } & kontrol negatif & $2,25000^{*}$ &, 69222 &, 004 &, 8105 & 3,6895 \\
& Perlakuan &, 12500 &, 69222 &, 858 & $-1,3145$ & 1,5645 \\
Perlakuan & kontrol negatif & $2,12500^{*}$ &, 69222 &, 006 &, 6855 & 3,5645 \\
& Kontrol positif &,- 12500 &, 69222 &, 858 & $-1,5645$ & 1,3145 \\
\hline
\end{tabular}

Hasil uji LSD dari Tabel 1 menunjukan bahwa:

1. Terdapat perbedaan bermakna dengan signifikansi $0,004(p<0,05)$ pada kadar kolesterol LDL kelompok hewan coba pada control negatif dan kelompok hewan coba kontrol positif

2. Terdapat perbedaan bermakna dengan signifikansi $0,006(p<0,05)$ pada kadar kolesterol LDL kelompok hewan coba kontrol negatif dan kelompok hewan coba perlakuan jus tomat

3. Tidak terdapat perbedaan yang bermakna dengan signifikansi 0,858 $(p>0,05)$ kadar kolesterol LDL kelompok hewan coba kontrol positif dan kelompok hewan coba perlakuan jus tomat

Hasil uji Kruskal-Wallis kadar kolesterol total tidak ada perbedaan bermakna rerata kadar kolesterol total tikus putih jantan galur Wistar antara kelompok kontrol negatif, kelompok kontrol positif, dan kelompok perlakuan jus tomat (Solanum lycopersicum L.)

\section{PEMBAHASAN}

Pada penelitian ini dilakukan induksi Aloksan dengan dosis $150 \mathrm{mg} / \mathrm{kgBB}$. Berdasarkan penelitian yang dilakukan oleh Chougale et al, (2007) membuktikan pada dosis $150 \mathrm{mg} / \mathrm{kgBB}$ terjadi peningkatan kadar glukosa dan kadar kolesterol lebih 
tinggi serta lebih stabil dibandingkan dosis $120 \mathrm{mg} / \mathrm{KgBB}$. Pada penelitian ini didapatkan bahwa peningkatan rerata kadar glukosa yaitu kelompok hewan coba tanpa induks aloksan sebesar 195,88 sedangkan kelompok hewan coba yang diinduksi aloksan sebesar 401,50. Peningkatan kadar glukosa pada hewan coba yang diinduksi aloksan menunjukkan bahwa aloksan merupakan agen diabetogenik yang akan menimbulkan terjadinya kerusakan sel $\beta$ pankreas.

Pada hewan coba yang diinduksi aloksan terjadi kerusakan sel $\beta$ pankreas, akibatnya terjadi penurunan kadar insulin. Kadar insulin yang menurun akan mengakibatkan peningkatan hormon sensitif lipase, keadaan ini mengakibatkan peningkatan kadar asam lemak bebas dan asam lemak dalam plasma, menjadi lebih dari dua kali lipat (Botham and Mayes, 2012). Penurunan kadar insulin mengakibatkan beberapa sel akan kekurangan energi sehingga sel $\alpha$ pankreas meresponnya dengan mensekresi glukagon. Glukagon akan mempengaruhi mobilisasi asam lemak bebas (Jonsten et al, 2006). Glukagon memiliki efek antogonis terhadap insulin, glukagon akan meningkatkan hormon sensitif lipase jaringan adiposa. Adanya peningkatan hormon sensitif lipase mengakibatkan peningkatan hidrolisis trigliserida sehingga Copyright (c) 2019 Leny Alimatul Husna kadar asam lemak bebas dalam darah meningkat.

Penurunan kadar insulin dan peningkatan sekresi glukagon memiliki efek yang sama terhadap peningkatan asam lemak bebas didarah sehingga meningkatkan jumlah asam lemak yang dapat digunakan untuk jaringan tubuh lain, salah satunya hepar (Hall and Edward 2011). Dihepar akan terjadi peningkatan Acyl-CoA yang merupakan permulaan pembentukan kolesterol. Melalui $\beta$-oksidasi proses Acyl-CoA diubah menjadi Acetyl-CoA dan selanjutnya akan menjadi HMG-CoA. Dan akhirnya akan membentuk mevalonat dengan bantuan HMG-CoA reduktase sebagai hasil akhir pembentukan kolesterol dihepar (Botham and Mayes, 2009).

Kolesterol akan diangkut oleh VLDL, lipoprotein endogen yang disintesis di hati, menuju ke jaringan tubuh lainnya. VLDL mengalami hidrolisis menjadi VLDL remnant (IDL) kemudian akan diubah menjadi LDL (Susilo, 2012). Peningkatan kadar LDL di dalam darah selain diakibatkan oleh konsumsi kolesterol yang tinggi, juga diakibatkan karena tingginya kadar VLDL (Botham and Mayes, 2009). Hal tersebut dibuktikan dengan adanya peningkatan kadar rata-rata kolesterol LDL dari kelompok kontrol positif yang diinduksi aloksan sebesar 8,38 
Pengaruh Pemberian Jus Tomat (Solanum lycopersicum L.) terhadap Kadar Kolesterol LDL... Leny Alimatul Husna, Louis Djoko, Fitri Handajani, Tri Martini

dibandingkan kelompok kontrol negatif tanpa perlakuan sebesar 6,13. Pada penelitian ini membuktikan bahwa induksi aloksan dosis $150 \mathrm{mg} / \mathrm{KgBB}$ dapat meningkatkan kadar kolesterol LDL pada hewan coba, yang ditunjukkan adanya perbedaan yang bermakna antara kelompok kontrol negatif tanpa pelakuan dengan kelompok kontrol positif yang diinduksi aloksan sebesar 0,004 $(P<0,05)$.

Pada hari ke-3 setelah induksi aloksan, kelompok perlakuan diberi terapi jus tomat selama 14 hari. Tomat memiliki kandungan likopen yang cukup tinggi. Bioavailibilitas likopen merupakan banyaknya likopen yang dicerna dan diabsorbsi, sehingga tomat mampu bekerja lebih optimal dijaringan target (Kamiloglu et al, 2013). Peningkatan bioavailibilitas likopen pada penelitian ini dilakukan dengan cara penghalusan tomat menggunakan blender eloktronik. Proses penghalusan tomat dengan di blender dapat mengubah ikatan trans- ke cissehingga dapat meningkatkan bioavailibilitas (Rao et al, 2006). Pemblenderan tomat diharapkan meningkatkan bioavailbilitas likopen pada jus tomat yang diberikan pada hewan coba. Peningkatan bioavailibilitas likopen diharapkan mampu melindungi kerusakan sel oleh radikal bebas. Antioksidan likopen mampu melindungi DNA dari kerusakan Copyright (c) 2019 Leny Alimatul Husna oksidatif, menonaktifkan hidrogen peroksidase dan nitrogen dioksida, serta melindung limfosit dari nitrogen oksida (NO) yang merusak membran dan mematikan sel (Sulistyowati, 2006). Likopen pada jus tomat diharapkan mampu menghambat enzim HMG-CoA reduktase yang akan menghambat pembentukan kolesterol di hepar dan juga meningkatkan reseptor kolesterol LDL di hepar yang akan menurunkan kadar kolesterol LDL (Rao, 2002).

Likopen terdapat dalam kromoplas tomat sebagai kompleks protein-karotenoid atau sebagai mikrokristal padat. Kromoplas merupakan organel sel pada tumbuhan yang memberi warna merah pada tomat. Likopen yang terikat dalam matriks jaringan bisa dipecah dengan pengolahan makanan (Kamiloglu et $a l, 2013)$. Nilai gizi dapat diketahui dengan cara mengukur bioavailabilitas nutrisi (Anese et al, 2013). Tomat yang diblender atau dijus meningkatkan biavailibiltasnya sehingga semakin tinggi bioavailibilatas tomat, maka nilai gizi tomat akan meningkat. Pengolahan makanan juga akan mengubah ikatan trans- ke cis- likopen yang lebih mudah diserap oleh tubuh (Stahl and Sies, 1992). Isomer cis- lebih meningkatkan efek antioksidan tomat dibandingan isomer trans- (Colle et al, 2010). 
Rerata kadar kolesterol LDL serum dari kelompok kontrol positif yaitu 8,38 dan kelompok kontrol perlakuan yang diterapi dengan jus tomat sebesar 8,25 menunjukkan penurunan namun hasil uji statistik didapatkan nilai signifikansi 0,858 $(P>0,05)$ menunjukkan tidak terdapat perbedaan yang bermakna.

Pada penelitian hasil rata-rata kadar LDL antara kelompok perlakuan dan kelompok kontrol positif mengalami penurunan yang tidak bermakna mungkin disebabkan oleh dosis jus yang kurang. Dosis yang digunakan dalam penelitian ini mengunakan dosis $11 \mathrm{mg} / \mathrm{kgBB}$ senilai dengan 11,28 ml/kgBB, sedangkan pada penelitian Al Mukhtar (2008) dosis jus tomat yang digunakan adalah $30 \mathrm{ml} / \mathrm{kgBB}$ per hari. Faktor-faktor lain yang dapat menganggu tingkat penyerapan karotenoid seperti spesies karotenoid, keterkaitan pada tingkat molekular, jumlah karotenoid, matriks, efektor, status nutrisi, genetik, faktor-faktor yang berhubungan dengan host dan interaksi melalui variabel-variabel tersebut dapat mempengaruhi bioavailibilitas karotenoid yang tertelan (Castenmiller and West, 1998).

Pembentukan kolesterol diawali oleh pengubahan asetil-KoA menjadi asetoasetil-KoA oleh tiolase, lalu asetoasetil-KoA diubah menjadi HMG-KoA oleh HMG-KoA sintase, dan HMG-KoA Copyright (c) 2019 Leny Alimatul Husna diubah menjadi mevalonat oleh HMG-KoA reduktase. Melalui beberapa tahap, yaitu pengubahan mevalonat menjadi unit isoprenoid, isoprenoid menjadi skualen, skualen menjadi lanosterol, dan akhirnya terbentuklah kolesterol dari lanosterol. Karena kadar asam lemak bebas darah meningkat, dan diikuti oleh peningkatan asetil-KoA, maka kadar kolesterol total darah juga meningkat (Murray et al, 2012). Hal ini dibuktikan dengan adanya peningkatan rata-rata kadar kolesterol total pada kelompok kontrol positif sebesar 71,63 $\mathrm{mg} / \mathrm{dL}$ dibandingkan kelompok kontrol negatif yaitu sebesar $57,63 \mathrm{mg} / \mathrm{dL}$. Namun, perbedaan kadar kolesterol total kedua kelompok ini secara statistik tidak bermakna $(p=0,141)$, kondisi ini mungkin disebabkan oleh faktor hewan coba seperti genetik dan kesehatan tikus, waktu perlakuan kurang lama sehingga kenaikan kolesterol total tidak meningkat secara bermakna pada kelompok induksi.

Untuk mengetahui kegunaan jus tomat dalam menurunkan kadar kolesterol total, maka kelompok perlakuan diberi jus tomat peroral 3 hari setelah diinduksi aloksan. Tomat mengandung beberapa nutrisi penting yang diperlukan tubuh seperti: vitamin A, B, C, E, K; karotenoid seperti $\alpha$-karoten, $\beta$-karoten, lutein, likopen; beberapa mineral seperti kalium, besi, fosfor; phytosterol (Bhowmik et al, 
Pengaruh Pemberian Jus Tomat (Solanum lycopersicum L.) terhadap Kadar Kolesterol LDL... Leny Alimatul Husna, Louis Djoko, Fitri Handajani, Tri Martini

2012). Kandungan nutrisi tomat yang menjadi fokus penelitian ini adalah likopen.

Likopen pada buah tomat memiliki bioavailabilitas paling tinggi dibandingkan sumber lain (Holzapfel et al, 2013). Salah satu manfaat likopen adalah sebagai HMG-KoA reduktase inhibitor, yaitu menghambat kerja enzim HMG-KoA reduktase yang mengubah HMG-KoA menjadi mevalonat, sehingga produksi kolesterol dalam tubuh menurun (Wang, 2012; Alvi et al, 2015).

Berdasarkan data penelitian yang diperoleh, rerata kadar kolesterol total kelompok kontrol positif adalah 71,63 $\mathrm{mg} / \mathrm{dL}$, sedangkan rerata kadar kolesterol total kelompok perlakuan, yaitu tikus yang mendapat terapi jus tomat, adalah 60,88 $\mathrm{mg} / \mathrm{dL}$. Keadaan ini menunjukkan penurunan kadar kolesterol total tikus yang mendapat terapi jus tomat, namun penurunan ini secara statistika tidak bermakna yaitu $p=0,270(p>\alpha)$. Kondisi ini mungkin disebabkan karena dosis pemberian jus tomat yang kurang optimal dan durasi pemberian jus tomat yang kurang lama sehingga kadar kolesterol total dan LDL belum dapat menurun secara signifikan. Kandungan likopen dalam jus tomat dapat menghambat aktivitas enzim HMG Co A reduktase yang merupakan enzim pengendali dalam sintesa kolesterol, sehingga sintesa kolesterol akan menurun Copyright (c) 2019 Leny Alimatul Husna dan berakibat terjadinya penurunan rerata kadar kolesterol LDL.

\section{KESIMPULAN}

Berdasarkan hasil penelitian di atas maka dapat disimpulkan bahwa Induksi aloksan dosis $150 \mathrm{mg} / \mathrm{Kg}$ BB dapat meningkatkan kadar kolesterol LDL serum darah tikus putih secara bermakna antara kelompok hewan coba tanpa induksi aloksan dengan kelompok hewan coba yang diinduksi aloksan. Pemberian jus tomat (Solanum lycopersicum L.) dengan dosis $11 \mathrm{gram} / \mathrm{Kg}$ BB selama 14 hari cenderung menurunkan kadar total kolesterol dan LDL serum

\section{SARAN}

Berdasarkan hasil yang dicapai dalam penilitian ini, maka dapat disarankan untuk melakukan penelitian pemberian jus tomat dengan dosis dan durasi yang berbeda sehingga bisa diketahui dosis dan waktu yang optimal agar dapat menurunkan kadar kolesterol.

\section{DAFTAR PUSTAKA}

American Diabetes Association, 2014. Diagnosis and classification of diabetes mellitus. Diabetes Care, 37(SUPPL.1): S81-90.

Anese M, Mirolo G, Beraldo P, Lippe G, 2013. Effect of ultrasound 
treatments of tomato pulp on microstructure and lycopene in vitro bioaccessibility. Food Chemistry, 136(2): 458-463.

Botham KM and Mayes PA, 2012. Chapter 15. Lipids of Physiologic Significance. In Harper's Illustrated Biochemistry.

Botham KM and Mayes PA, 2009. Sintesis, Transpor, \& Ekskresi Kolesterol. In Biokimia Harper: 239-249.

Castenmiller JJM and West CE, 1998. Bioavailability and bioconverion of carotenoids. Annual Review of Nutrition. 18: 19-38.

Charles N, 2014. Effect of Thermal Processing on Lycopene, Beta-Carotene and Vitamin C Content of Tomato [Var.UC82B]. Journal of Food and Nutrition Sciences.2(3): 87.

Chougale AD, Panaskar SN, Gurao PM, Arvindekar 2007. Optimization of Alloxan Dose is Essential to Induc Stable Diabetes for Prolonged Period. Academic Journal Inc. . 2(6): 402-408

Colle I, Buggenhout SV, Loey AV, Hendrickx M, 2010. High pressure homogenization followed by thermal processing of tomato pulp: Influence on microstructure and lycopene in vitro bioaccessibility. Food Research International. 43(8): 2193-2200.

Engelmann NJ, Clinton SK, and Erdman Jr. JW, 2011. Nutritional aspects of phytoene and phytofluene, carotenoid precursors to lycopene. Advances in Nutrition, 2(1): 51-61.

Hall and Edward J, 2011. Guyton and hall textbook of medical physiology thirteenth edition,

Hermansyah, 2014. Efek Ekstrak Kayu Manis (Cinnamomum cassia) tehadap Kadar Glukosa Darah, Berat Badan, dan Kolesterol pada Tikus Jantan Strain Sparague dawley yang Diinduksi Aloksan.

International Diabetes Federation (IDF), 2017. IDF Diabetes Atlas 8th edition.

Iswari RS, 2009. Perbaikan Fraksi Lipid Serum Tikus Putih Hiperkolesterolemi Setelah Pemberian Jus dari Berbagai Olahan Tomat. , pp.1-6.

Jonsten S, Mutmainnah and Hardjoeno, 2006. Profil lipid Penderita Diabetes Melitus Tipe 2. Indonesian Journal of Clinical Pathology and Medical Laboratory. 13(1): 20-2.

Kamiloglu S, Boyacioglu D and Capanoglu E, 2013. The effect of food 
Pengaruh Pemberian Jus Tomat (Solanum lycopersicum L.) terhadap Kadar Kolesterol LDL...

Leny Alimatul Husna, Louis Djoko, Fitri Handajani, Tri Martini

processing on bioavailability of tomato antioxidants. Journal of Berry Research.3(2): 65-77.

Latifah E, 2013. Khasiat Jus Tomat untuk Memperbaiki Profil Lipid.

Lenzen S, 2008. The mechanisms of alloxan- and streptozotocin-induced diabetes. Diabetologia. 51(2): 216-226.

Rao AV, 2002. Lycopene, tomatoes, and the prevention of coronary heart disease. Lycopene and Disease Prevention, 227(10), pp.908-913.

Rohilla A and Ali S., 2012. Alloxan Induced Diabetes: Mechanisms and Effects. International Journal of Research in Pharmaceutical and Biomedical Science. 3(2): 819-823.

Setiawan R, 2010. Pengaruh Pemberian Ekstrak Kelopak Bunga Rosela (Hibiscus sabdariffa L) Terhadap Penurunan Kadar Gula Darah Tikus Putih (Rattus norvegicus) Yang Diinduksi Aloksan.

Stahl W and Sies H, 1992. Uptake of lycopene and its geometrical isomers is greater from heatprocessed than from unprocessed tomato juice in humans. Journal of Nutrition. 122(11):2161-2166.

Sulistyowati Y, 2006. Pengaruh Pemberian Likopen Terhadap Status Antioksidan ( Vitamin C, Vitamin E dan Gluthathion Peroksidase ) Tikus ( Rattus Norvegicus Galur Sprague Dawley ) Hiperkolesterolemik. Program Studi Magister IImu Biomedik Program Pascasarjana Universitas Diponegoro.

SusiloTY, 2012. Khasiat Minyak Zaitun ( Olive Oil) dalam Meningkatkan Kadar HDL ( High Density Lipoprotein ) Darah Tikus Wistar Jantan. 